\title{
THE POWER OF LITERARY WORKS IN BUILDING YOUNG ENTREPRENEUR'S CHARACTER AS REFLECTED IN BUYA HAMKA'S FICTION
}

\author{
Cindy Kurnia Octaviyanti*
}

\begin{abstract}
* Affiliation:
Universitas Islam Sultan Agung, Jalan Raya Kaligawe km. 4, Semararang, Indonesia
\end{abstract}

cindyoctavi@gmail.com

\begin{abstract}
:
War, poverty, hunger, and health issues still remain big problems in global era. Facing an era like today, the youth can not only sit and wait for chance to come to them. Preparing the youth is one of the ways to overcome the problems. This idea is recognized by the youths themselves and has awakened an awareness to build leader characters since the very first time. There are several ways to create the leader characters and one and the most important of them is by modeling. This paper discusses how Buya Hamka's fiction can serve as leader model for youths to be a successful entrepreneur. Through his influential literary works, Buya Hamka has introduced and exemplified the youths to face an era like today. This paper uses descriptive qualitative approach which identified the power of literary works in leading the world as seen in Buya Hamka. The data for analysis were collected by library research. Even though Buya Hamka lived in the past, his spirit and ideas are still alive and relevant that young people can adopt in the present time. Buya Hamka is an exemplary and inspiring entrepreneur who had devoted his life for people, the nation and the change of a better world.
\end{abstract}

Keywords: Buya Hamka, leader characters, youth, literary work.

\section{INTRODUCTION}

One of the ways for people to express their selves is by writing. Writing activity becomes crucial thing for human life since it helps people to express their opinion and speak through the words. One of the results of writing activity is the existence of literature in the form of literary work. Literary work has become the reflection of social phenomenon that happens in the world because an author's idea usually not only comes from their imagination, but also from the condition or phenomenon that happens around him. Literature which consist of those writing which interpret the meanings of nature and life, in words of charm and power, touched with the personality of the author in artistic forms of permanent interest. ${ }^{1}$ Literary work is a way for people see through one's eye in form of words.

${ }^{1}$ Henry Jackson Van Dyke, American author, educator, and clergyman 
One of literary works classification is fiction. Fiction has always been interesting to read. A fiction usually tells about the vary stories of human life such as family story, love story, friendship, and many more. As the result, a literary work especially fiction could be a mirror of someone's life because it tells about the human life and social phenomenon that happens in society at certain time. A fiction is sometimes a real story in a society, and sometimes it is a real story but the author embellishes the story with another fiction. As the society's reflection, reading literary work is more than an amusing activity. Reader could take some other advantages such as expanding the reader's imagination and knowledge, and take some moral of values of the literary work. Literary work even could influence people's mind and character in their lives. Eric Chock, a Hawaiian poet, scholar and editor argued "Literature is a way to understand life, to appreciate living and therefore to participate in life to the fullest of your potential." From the statement, it proofs that literary work which belongs to literature is not only containing of hundred even thousand meaningless words, but it is also merely a weapon to inspire people. There are many objects in literary work that can be learnt by the reader, such as from the story or the character inside it.

There are many famous author of literary work. One of them is Buya Hamka from Indonesia. He takes role in almost all activities of human life for caring and changing. As more than a writer, his activity as ulama ${ }^{2}$, political activist and philosopher makes him as multitalented ulama that Indonesia ever has. His experiences and knowledge make his literary work could inspire people and help the young entrepreneur to have an unconscious character building after reading his work. Even tough Hamka is one of figures lived in the past, but his masterpieces in form of literary works are not only useful in the past. Hamka is a role model for all eras because his productivity and his strong character in maintain his principal. Through his literary works Buya Hamka delivers some moral values in life such as forgiving people and maintaining his belief in any situations of life. He also becomes one of time-honored person in the world especially in Indonesia because his productivity and concern for the country's development. Soekarno the first president of Indonesia and who were known as Buya Hamka's political enemy stated "Bila aku mati kelak, minta kesediaan Hamka untuk menjadi imam shalat jenazahku." (Hamka, 256) The above statement tells that Soekarno wanted Hamka to be the Imam in his corpse praying. It shows that Buya Hamka is respected by people because of his character, even he was also respected by his political enemy. His character, makes his literary work is so powerful with the positive things inside.

Considering that the literary works of Buya Hamka belongs to all eras, not only the past era but also until today era, his literary works become an appropriate and powerful weapon to face an era like today. Below is a quotation taken from Buya Hamka's novel "Tenggelamnya Kapal Van Der Wijck”:

"Anak lelaki tak boleh dihiraukan panjang, hidupnya ialah buat berjuang, kalau perahunya telah dikayuhnya ke tengah, dia tak boleh surut palang, meskipun bagaimana besar gelombang. Biarkan kemudi patah, biarkan layar robek, itu lebih mulia daripada membalik halauan pulang."

\footnotetext{
${ }^{2}$ Ulama is a Muslim scholars recognized as having specialist knowledge of Islamic sacred law and theology
} 
The narration above is one of narration in "Tenggelamnya Kapal Van Der Wijck" novel. It is an advice for a man to not give up in his life, because a man is like a ship, once sailing he doesn't allow stopping no matter what happen. The short narration from Hamka's novel proves that there is a good thing that could be taken from Hamka's novel which needed by youth to face modern era. An era which still remain some big problems and an era which doesn't allow anyone to only sit and watch what's happening. Today is an era that needs everyone's contribution to fix the problem especially the youth contribution. Together with the on-fire spirit of the youth combining their intelligence also, the world should have youth to make alteration movement of the world. The youth with intelligence becomes the young entrepreneur that need soon to turn into a leader to tackle down the problematic world. A way of altering youth from common young generation into young entrepreneur who lead the world is by modeling, because young people need models, not critics. ${ }^{3}$

\section{LITERATURE REVIEW}

\section{Getting Acquainted with Buya Hamka}

Professor Doctor Haji Abdul Malik Karim Amrullah is better known as Buya Hamka born in Kampung Molek, Maninjau, West Sumatera, Indonesia, on February $17^{\text {th }} 1908$. He was the first children of seven brothers from Dr. H. Abdul Karim Amrullah and Siti Safiyah. Its name of "Hamka" was actually the acronym of his full name, Haji Abdul Malik Karim Abdullah. While the word "Buya" actually was coming from the Arabic word "Abi" or "Abuya" which means "My Father" or "The Honorable Person". He was raised in a family of devout Muslims, since his father was a clerical reformer of Islam in Minangkabau.

If some famous figures in the world spend some years in formal schools to seek knowledge, Hamka has different experiences. Hamka only had two years of elementary school in Maninjau Elementary School. After that, when he was in 10 years old, Hamka preferred to focus in religion knowledge in Sumatera Thawalib in Padang Panjang, an Islamic school established by his father in 1906. There, Hamka started to learn Islam and Arabic language more seriously. He was known as a never-satisfied person since he was child.

When he was in 16 years old, the young Hamka went to Java Island to seek knowledge and to expand his view with Islamic movement leader, such as Haji Omar Said Chakraaminoto, K.H. Fakhrudin, Ki Bagus Hadi Kesumo, and many more. Hamka joined vary discussions and training of Islam movement, in Abdi Dharmo Pakualaman, Yogyakarta. Before returning to Minangkabau, he had wandered into Bandung and met with Masyumi ${ }^{4}$ leaders such as Ahmad Hassan and Mohammad Natsir, which gave him the opportunity to learn to write in Pembela Islam magazine. In 1925, Hamka went to Pekalongan to meet Sutan Mansur Ahmad Rashid, who was the chairman of Muhammadiyah, Pekalongan at the time, and learn Islam to him. To expand his knowledge in Islam, in 1927 Hamka also went to Mecca by his own expenses. In addition, it was also his first Hajj ${ }^{5}$ pilgrimage. Not only religion knowledge, he

\footnotetext{
${ }_{3}^{3}$ John Robert Wooden, an American basketball player, coach, and renowned motivational speaker and writer

${ }^{4}$ Masyumi is (Partai Majelis Syuro Muslimin Indonesia - Council of Indonesian Muslim Associations) was a major Islamic political party during the Liberal Democracy Era in Indonesia. It was banned in 1960 by President Soekarno

${ }^{5} \mathrm{Hajj}$ is the Muslim pilgrimage to Mecca in the last month of the year (in Islamic calendar), and that all Muslims are expected to make at least once during their lifetime
} 
also mastered some other knowledge such as philosophy, literature, history, sociology, and politics. The interesting fact is Hamka learned the knowledge by himself. Moreover John L. Esposito in "Oxford History of Islam" mentioned Hamka equally with Sir Muhammad Iqbal ${ }^{6}$, Sir Syed Ahmad Khan ${ }^{7}$, and Muhammad Asad ${ }^{8}$. Hamka got his doctor honoris causa from two universities. The first one was from Al-Azhar University, Cairo, Egypt, and the other was from University Kebangsaan, Kuala Lumpur, Malaysia. His "Professor" title was awarded by Moertopo University, a private university in Jakarta, Indonesia.

Buya Hamka in Indonesia is known as an Ulama who delivers his thought in his novels. There are more than 113 books, including novels, short stories, histories, poems, religious books, and tafsir". It is started when he was in Mecca, he became correspondent of the daily newspaper Pelita Andalas and also worked at a printing company. Hamka came back to Medan in 1936 and worked as an editor and the head of editorial in "Majalah Pedoman Masyarakat"an Islamic magazine, established by him self and M. Yunan Nasution. After that, Hamka wrote some novels, started with "Dibawah Lindungan Ka'bah”, "Tenggelamnya Kapal Van Der Wijck", "Merantau ke Deli" and many more. Most of his books become the best seller in Indonesia and Malaysia at the time.

Buya Hamka's personality is described clearly in an autobiography of him by Irfan Hamka as known as Buya Hamka's son. In this book, Hamka is described as a distinct yet gentle. He is type of person who easy to forgive people. Hamka is distinct with everything related with his religion and principal. He rejected things that he thought it breaks the rule in religion. His distinct seen when he was as the chairman of MUI ${ }^{10}$ rejected the government's rule to hold Christmas celebration, which include Muslim inside the celebration. About his rejection toward the rule, his statement is so famous until now:

"Kita sebagai ulama telah menjual diri kita kepada Allah semata. Ulama yang telah menjual diri kepada Allah, tidak bisa dijual lagi kepada pihak manapun. Ulama ibarat kue bika. Dari bawah dipanggang api, dan diatas pun dibakar api. Begiu juga ulama, dari bawah oleh umat, dan dari atas oleh pemerintah." (Hamka, 255)

From the narration above which narrated by Buya Hamka, it shows his responsibility as Ulama. Hamka thinks that the responsibility of becoming Ulama is not only for Muslim but also for God.

Hamka has a habit in reciting Qur'an for 5 to 6 hours per day. He really loves Qur'an and he reads more after his wife passed away. "Setelah Ummi wafat, Ayah mengkhatamkan Al-Qur'an sebanyak 6-7 kali dalam sebulan." (Hamka, 213). From the quotation above, it shows that Hamka is a religious man and so strong in terms of maintaining faith. Even tough he is distinct in terms of faith and belief, but Hamka is tolerance with all peole even it is not a Muslim. Because he is an open-minded person of one's belief, he could respect the difference, and his relation is across ethnic and religion. Its open-minded also shown by the books that he read, such as book by Sigmund Freud, Albert Camus, William James, and many more.

\footnotetext{
${ }^{6}$ A poet, philosopher, and politician, and scholar in British India who inspires the Pakistan movement.

${ }^{7}$ An Indian Muslim pragmatist, Islamic modernist, philosopher, and social activist of nineteenth century India.

${ }^{8}$ One of the most influential Muslims of the twentieth century.

${ }^{9}$ Tafsir is interpretation or exegesis usually of the Qur'an.

${ }^{10}$ MUI stands for Majelis Ulama Indonesia (Indonesian Ulema Council), a top Muslim clerical body.
} 


\section{Leader and Its Character}

Era like today is an era where everything is in contrast. While in some parts of people in this world eat delicious food, in the other parts still there are some people who do not have any money to buy food. While some people live in peace, in other part many people dead because of war. When some people busy with their own high-technological gadget, some other don't even know how to read alphabet. Those phenomenons are actually clear enough as the urgency of the world's problem today. It should be everyone's awareness that those problems do not only become the government's job but also everyone's job. Since war, poverty, and hunger is related with humanity. It's no longer the time to only rely on one person, that consider as the leader, but this is the time for every one to be the leader to solve the problems. Because actually leaders don't create follower, they create more leaders. ${ }^{11}$

There are many definitions of leader and its character. Even some theorists also have different opinion toward this. Before elaborating the characters of leader, the word "Leader" needs to be described first. In terms of leader, there is always a leadership. The most important thing when talking about leader is a leadership soul, it means that a leader must be someone who is capable enough to lead.

"The study of leadership has been an ongoing process for many, many years and has been broadly defined as a process of social influence. Leadership, unlike management, is not dependent on position, title or privilege; instead it is an observable, understandable, and learnable step of skills that can be mastered by anyone that is willing to take the time and put forth the effort to learn them" (Yukl, 1998).

The narration above shows that leadership does not only come from people who have title or privilege, but it is possible to come from everyone who are has the willingness to understand and learn. "Leadership is the ability to influence others by setting and inspiring example." (Prewitt, 13)

From above explanation, it concludes that leader is not always the one who can solve everything, but the one who has willingness to do something through any media. A leader is the one who influence the society, and inspire it. When someone inspires other, it has been clear that he just done something impressive for the environment, include overcome the problem. While Bill Gates the co-founder of Microsoft stated that a leader will be those who empower others. So, by defining the word "leader" also stated indirectly how the characters of leader are. That the one who responsible enough with his self, so has an effort to empower his environment. Because leaders think and talk about the solutions, followers think and talk about their problems. ${ }^{12}$ When each person realized the duty in his environment, it is also a step to overcome the problems in the environment.

\section{METHOD}

This paper uses descriptive qualitative approach which tries to analyze how Buya Hamka can serve as leader model for youths to be a successful entrepreneur through his literary works and how literary works of Buya Hamka become the media to prepare the young entrepreneur

11 Tom Peters is an American writer on business management practices, best known for in Search of Excellence. 12 Brian Tracy is a chairman and CEO of Brian Tracy International, a company specializing in the training and development of individuals and organizations. 
to be a character leader in modern era. In this paper literary works is expected to be the media for youth to become a leader. As the result, Buya Hamka's literary works are the role model for the youth to not only becomes a common leader, but leader with character as reflected in Buya Hamka.

\section{RESULT}

While talking about the duty in environment, actually the earlier people realize of the duty, the better it will be. When someone realizes that he has to solve the problem in his environment at the very first day, it will be very useful to make a better world. It means that it should be since at the young age, people aware of the condition surround them and the awareness should be planted at the earliest time as possible. Anne Walraven, a UN youth delegate, even says that "The role of younger generation is crucial. The world needs us." It shows that youth is really needed to change the world, to care with the environment, and have the power to do those things. John Liu a also stated his belief with youth "Our youth action team promotes a stronger connection between young people and the community. We seek potential leaders who have he energy and motivation to contribute." The quotation above shows that the urgency of the world right now is not waiting until reach a mature age to contribute to community, but since the young age indeed the change happens.

In this case, youth are one of the most important agents to give alteration in the world. It is better to make change since the very first time so the change will give a long-term impact. Youth with their spirit should be very influential people to make the world better. When the young people are so passionate to make a change, then the older or even the younger of them will just follow the path because of the inspiration. This is not the time anymore for people to only rely on the government. Because facing today era can not pass by only blaming the government for the world's problem, facing today's era is the time for us to do some actions. This is why very important for youth to recognize that their duty is not only having fun and enjoy the facility, but also having fun with the positive way such as become a very care people to the world. When youth do it and make it trend, other youth who haven't do such things, will just follow it. Youth is very important and becomes the special one while changing the world because his spirit. Every youth has to know that he is a leader. When he realizes it, he will have a sense of responsibility in their life. Even only a little change, but it is still change.

\section{DISCUSSION}

Elaborating the word literary work, Salman Rushdie, one of famous authors in the world stated that "Literature is where I go to explore the highest and lowest places in human society and in the human spirit, where I hope to find not absolute truth but the truth of the tale, of the imagination and of the heart." From the above quote it shows that literary work is captured every layer of human life, without focusing too much in finding the fact but both reality and imagination. In conclusion, it is definitely true that literary work is composed by reality, author's experience, and imagination. So, it not only helps the author to express his self, but also becomes reflection of a society since the content is influenced by what happens in society. This is especially happened when writing fiction. 
In writing fiction, narrated by Irfan Hamka, Buya Hamka also influenced by his personal life. Accumulated from his fiction, most settings take place in Minang, West Sumatra, recalling that Buya is come from Minang, West Sumatra. His fiction also doesn't far away from his personal character that is strict in religion and faith, so the fiction also religious. Mostly the main character in the novel depicted as a religious man, patient, kind hearted, but easy to forgive people. Those characters also include as the things that reader could imitate in real life. In fact, Buya Hamka delivers some good things that reader could take as the life guidance.

This paper provides Buya Hamka's literary work as the media to young entrepreneur in their preparation to be a successful entrepreneur. It means that between literary works and leadership has correlation each other. Since literary works are mostly influenced by the author's experience or environment, it shows that there are messages behind the story. Reading literary works is not only entertaining, but also provides moral values that can soften manners and supports the formation of character and personality based on faith (Rudy, 2009). Based on the quotation, it concludes that there are lessons that reader could take when reading literary works. There are lessons for life, which can influence the reader's manner, character and personality.

The role of literary works in building character is so crucial. By reading the literature, the students know the characters and understand the motives done by the characters so that they comprehend the reasons for the behavior of the characters. (Husniah and Yudhi, 2008). It means that literary works work in building character, because readers tend to learn something from the story. Regardless, literary work also a fun way to have such a self-motivation in building character unconsciously. Since, character is very important in life.

Rosenblatt (1983) defines more functions of literature: (1) Literature endorses the need for imagination in democracy; (2) Literature diverts imagination, behavior, attitudes, emotions, social values, and personality; (3) Literature presents the possibility of differences in outlook on life, the pattern of relationships, and philosophy; (4) Literature helps in the selection of different imaginations through literature review experience; (5) The experience of literature allows the readers to view his own personality and his problems objectively and solve it better; and (6) Literature gives reality to the adults of different value systems so that they are free from fear, guilt, and uncertainty. From the quotation above, we can pointed out that basically literature is functioned as character building of the reader.

Character is correlated with one's personality. Personality also correlated with the duty and role of his existence in society. Why someone always responsible for society? Because humans is created as social living thing, which depend on each other. That is the reason why one's personality, also takes role in the social life. When the character is already shaped by positive things, it is not possible for someone to heal the society and be useful in the society. However, building character is succeed not only through join such a formal training, but it is also can be succeeded by reading literary work as well.

Literary work that could shape character also reflected in Buya Hamka's fiction. Together with Buya Hamka's knowledge and experiences, his literary works tell many moral values for life, and he also criticize things that break the religion rules through literary works. In the same time, Hamka's literary work also kind of multi-eras literary works because the value behind the story. 
"Nikmat Ilahi ada di sekeliling tiap-tiap insan, ada di dusun, ada di kota, ada di gunung dan ada di lurah, ada di daratan dan ada di lautan. Tetapi nafsu tiada merasa puas, atau tidak ingat nikmat yang di kelilingnya itu; dia hanya melihat kekurangannya. Yang senantiasa diperhatikannya ialah nikmat yang ada di tempat lain, dan yang di tangan orang lain. Kelak kalau dia ada kesempatan pindah ke tempat yang dilihatnya itu, dia menyesal dan dia teringat pulang, yaitu pada hari yang tiada berguna padanya penjelasan lagi." (Hamka, Tenggelamnya Kapal Van Der Wijck)

The quotation is taken from "Tenggelamnya Kapal Van Der Wijck" novel. It tells an ungrateful condition of human in life. Human always want more than they get. From the narration, it proofs that the content in Buya Hamka could be the media in building character.

The multi-eras fiction by Buya Hamka also becomes the reason so Buya Hamka's literary works could be the media for everyone includes the young generation. Recalling that young generation is the agent of change in the earlier explanation, so reading Buya Hamka's literary works could help the young generation, especially young entrepreneur prepare their selves to be a successful entrepreneur.

Being a successful entrepreneur is not enough by only become entrepreneur. As the urgency of today is youth need to grow up positively, with good character. In addition, youth have to build their character as good as possible so can be useful for their surrounding. While youth is tend to learn in a fun way. In the other words, they want to get amusement and lessons in the same time, and reading novel becomes an option of that demand. Since Buya Hamka's literary work contains the positive things such as responsibility, culture, religion, and many more, so after reading the novel, young generation is basically take the moral values and implement it in real life. These things help the young entrepreneur in preparing the youth to be a successful entrepreneur. Through the characters, the story, and the meaningful words inside the novel, youth will be influenced and learned something from it. As the result, when one young generation reads it and influence it in a community, other will follow and make it trend among the youth. It makes the youth tend to spread a positive thing, and little by little overcome the problem in the surrounding because the good character.

\section{CONCLUSION}

Related with above explanation, it concludes that young generation is powerful enough to influence people in positive way. Even many success people that appear in above explanation believe that youth is creating to make a change. Especially as young entrepreneur, to be useful in society has been the obligation, because to be useful is the essence of human. While to make that dream comes true is not impossible for the youth, as long as the youth it self have good personality so can comforting each other. Through literary work youth could also build their character. One of novel that helps to build character is novels by Buya Hamka. In the end, appreciating a literary work is not only by reading it but also by implementing the positive thing in the real life. 


\section{REFERENCE}

Almerico. Gina. M. (2014). Building Character through Literacy with Children's Literature. Research in higher education journal volume 26.

Hamka, Buya. (1938). Tenggelamnya Kapal Van Der Wijck. 978-979-418-055-622.

Hamka, Irfan. (2013). Ayah... (Kisah Buya Hamka). Republika.

Hamka, Rusydi. (1983). Pribadi dan Martabat Buya Prof. Hamka. Pustaka Panjimas.

Panitia Peringatan Buku 70 Tahun Buya Prof. Dr. Hamka (1983). Kenang-kenangan 70 Tahun Buya Hamka. Yayasan Nurul Islam.

Husniah, R., \& Yudhi, A. (2008). Character education through moral approach in the teaching of literature. Paper presented in Literature International Conference XIX/HISKI.

Inderawati, Rita. (2012). The Development of Literary Appreciation Instrument in Building Students' Character. David Publishing. 1539-8072.

Prewitt. James, Richard Weil and Anthony McClure. (2011). Developing Leadership in Global and Multi-cultural Organizations. International Journal of Business and Social Science.

Rosenblatt, L. M. (1983). Literature as exploration (3rd ed.). The Modern Language Association of America.

Rudy, R. I. (2009). Reader response and visual symbols-based learning to develop literary appreciation and English language ability. Forum Kependidikan.

Shobahussurur. (2008). Mengenang 100 tahun Haji Abdul Malik Karim Amrullah Hamka. 979177-850-7.

(1982). Perjalanan Terakhir Buya Hamka. Panji Masyarakat.

www.bio.or.id/biografi-buya-hamka/ . Retrieved December 27, 2015.

\section{ACKNOWLEDGEMENT}

I would like to express my deepest gratitude to my Allah Subhanahu Wa Ta'ala who bless me much more than I deserve, who empowers me, and loves me, so I can accomplish this paper. My special gratitude goes to Prof. Doctor Buya Hamka, who inspires and entertains with all his masterpieces especially his remarkable fictions, I am so proud to have you in my paper. Hopefully this paper will be useful for the readers.

\section{(Footnotes)}

\footnotetext{
${ }^{1}$ Henry Jackson Van Dyke, American author, educator, and clergyman

${ }^{2}$ Ulama is a Muslim scholars recognized as having specialist knowledge of Islamic sacred law and theology

${ }^{3}$ John Robert Wooden, an American basketball player, coach, and renowned motivational speaker and writer
} 